University of Nebraska - Lincoln

DigitalCommons@University of Nebraska - Lincoln

\title{
LIPOGENESIS IN ADIPOSE TISSUE FROM OVARIECTOMIZED AND INTACT HEIFERS IMMUNIZED AGAINST ESTRADIOL AND(OR) IMPLANTED WITH TRENBOLONE ACETATE
}

\author{
L. C. St. John
}

Texas A \& M University - College Station

P. A. Ekeren

Texas A \& M University - College Station

J. D. Crouse

U.S. Departement of Agriculture

B. D. Schanbacher

USDA-ARS

S. B. Smith

Texas A \& M University - College Station

Follow this and additional works at: https://digitalcommons.unl.edu/usdaarsfacpub

Part of the Agricultural Science Commons

St. John, L. C.; Ekeren, P. A.; Crouse, J. D.; Schanbacher, B. D.; and Smith, S. B., "LIPOGENESIS IN ADIPOSE TISSUE FROM OVARIECTOMIZED AND INTACT HEIFERS IMMUNIZED AGAINST ESTRADIOL AND(OR) IMPLANTED WITH TRENBOLONE ACETATE" (1987). Publications from USDA-ARS / UNL Faculty. 775. https://digitalcommons.unl.edu/usdaarsfacpub/775

This Article is brought to you for free and open access by the U.S. Department of Agriculture: Agricultural Research Service, Lincoln, Nebraska at DigitalCommons@University of Nebraska - Lincoln. It has been accepted for inclusion in Publications from USDA-ARS / UNL Faculty by an authorized administrator of DigitalCommons@University of Nebraska - Lincoln. 


\title{
LIPOGENESIS IN ADIPOSE TISSUE FROM OVARIECTOMIZED AND INTACT HEIFERS IMMUNIZED AGAINST ESTRADIOL AND(OR) IMPLANTED WITH TRENBOLONE ACETATE ${ }^{1}$
}

\author{
L. C. St. John ${ }^{2}$, P. A. Ekeren ${ }^{2}$, J. D. Crouse ${ }^{3}$, \\ B. D. Schanbacher ${ }^{3}$ and S. B. Smith ${ }^{2}$ \\ Texas A\&M University, College Station 77843 \\ and \\ U. S. Department of Agriculture ${ }^{3}$ \\ Clay Center, NE 68933
}

\begin{abstract}
Forty-two heifers were allotted randomly to six treatment groups: 1) intact controls, 2) intact heifers implanted with trenbolone acetate, 3) ovariectomized heifers, 4) ovariectomized heifers implanted with trenbolone acetate, 5) intact heifers immunized against estradiol and 6) intact heifers immunized against estradiol and implanted with trenbolone acetate. Blood titers of estradiol-17 $\beta$ were increased over 100 -fold in heifers immunized against estradiol in Freund's complete adjuvant or saline:squalene/arlacel containing Mycobacterium. Lipogenic enzyme activities and acetate incorporation into fatty acids were increased in subcutaneous adipose tissue obtained at slaughter from heifers receiving immunization or the combination of immunization and trenbolone acetate. The increased lipogenic capacity was not reflected in either cell diameter or cells per gram adipose tissue. Ovariectomy in combination with trenbolone acetate caused the lowest activities for all enzymes measured. This treatments also caused the greatest decrease in cell diameter, which resulted in the largest number of cells per gram of adipose tissue. Trenbolone acetate alone had no detectable effect on lipogenesis in the intact heifer, but the combination of ovariectomy and trenbolone acetate caused substantial decreases in enzyme activities, in most cases a significant decrease as compared with ovariectomized heifers. The data suggest that trenbolone acetate is able to depress lipogenesis only when not competing with the effects of circulating estradiol.

(Key Words: Lipogenesis, Ovariectomy, Trenbolone, Estradiol, Immunization.)
\end{abstract}

\section{Introduction}

The growth and distribution of fat have been of considerable importance both to the producer and the consumer of animal products. The beef industry has been interested in the subject as it relates to the heifer, because the heifer is usually fatter and thus may be valued lower than the steer at market weight. The differences in fat partitioning and live weight gains of heifers usually have resulted in a price differential of up to $\$ 4 / \mathrm{cwt}$ as compared with the steer. However, the use of anabolic agents may be able to

${ }^{1}$ Technical article no. 21745, Texas Agr. Exp. Sta. These data have been reported previously in preliminary form. J. Anim. Sci. 61 (Suppl. 1):266, (Abstr. 145).

${ }^{2}$ Meats and Muscle Biol. Sec., Dept. of Anim. Sci., Texas Agr. Exp. Sta., Texas A\&M Univ., College Station.

${ }^{3}$ Meat Anim. Res. Center, Clay Center, NE.

Received July 7, 1986.

Accepted January 15, 1987. reduce this difference. Heitzman (1979) has suggested that the combination of androgen and estrogen is necessary for maximum growth potential. However, estradiol implantation in bulls can result in poorer growth performance (Schanbacher et al., 1983).

Androgens are thought to act directly at the muscle cell (Young and Pluskal, 1977) and are known to increase protein accretion while possibly reducing protein turnover rates (Heitzman, 1978). The majority of these studies emphasize the effects of anabolic hormones on the muscle cell or merely on carcass traits. Little research has been reported dealing with the effect of androgens or androgen-like compounds on adipose tissue. Prior et al. (1983) demonstrated that lipogenesis (as measured by lipogenic enzymes and fatty acid synthesis in vitro) was elevated in subcutaneous adipose tissue from bulls implanted with estradiol, which likely was the result of depressed testosterone titers in the implanted bulls (Schanbacher et al., 1983). In this investigation, specific aspects of fatty acid 
synthesis and adipose tissue growth were investigated to clarify the mechanisms that are affected as a result of ovariectomy, trenbolone acetate implants and(or) immunization against estradiol.

\section{Materials and Methods}

Ninety crossbred heifers, Simmental-sired by Angus or Hereford dams or Angus $x$ Hereford heifers were allotted randomly to one of six treatment groups at 5 mo of age. These consisted of: 1) intact heifers injected with $1 \mathrm{ml}$ of $.9 \%$ saline solution $(\mathrm{N}=5) ; 2)$ intact heifers implanted in the ear with $200 \mathrm{mg}$ of trenbolone acetate at four 56-d intervals, with a $60-\mathrm{d}$ withdrawal period $(\mathrm{N}=7) ; 3$ ) ovariectomized heifers injected with $.9 \%$ saline $(\mathrm{N}=5) ; 4)$ the combination of ovariectomy and trenbolone acetate $(\mathbf{N}=8) ; 5)$ intact heifers immunized against estradiol by injection along the udder $(\mathrm{N}=5)$; and 6) the combination of immunization and trenbolone acetate treatments $(N=5)$. The numbers in parentheses indicate how many heifers (selected at random) were utilized for the biochemical measurements indicated below.

Heifers were injected subcutaneously along the udder with saline or with $1 \mathrm{mg}$ of $(1,3,5,10)$ estratrien-3,17 $\beta$-diol-6-one carboxymethoxime ${ }^{4}$ in $1 \mathrm{ml}$ of Freund's complete adjuvant (FCA; $1: 1, \mathrm{v} / \mathrm{v})$ or saline:squalene/arlacel $(1: 5: 5, \mathrm{v} / \mathrm{v} / \mathrm{v})$ containing either Mycobacterium tuberculosis ${ }^{5}$ or the muramyl dipeptide adjuvant CGP $11637^{6}$. Booster immunizations of $1 \mathrm{mg}$ of antigen and the respective adjuvant-vehicle combination were given 28,79 and $162 \mathrm{~d}$ after the initial immunization.

Blood samples were collected 57, 112 and $217 \mathrm{~d}$ after the initial immunization and titers were determined by a charcoal precipitation assay utilizing tritiated estradiol-17 $\beta$ (Schanbacher and Ford, 1976). The titers were expressed as the percentage of radiolabeled estradiol- $17 \beta$ specifically bound in sera diluted $1: 100$.

Animals were fed an $\mathbf{8 5 \%}$ total digestible nutrient, $10.5 \%$ crude protein corn-corn silage diet,

\footnotetext{
${ }^{4}$ Steraloids, Inc., Wilton, NH.

${ }^{5}$ Difco Laboratories, Detroit, MI.

${ }^{6}$ Ciba-Geigy AG, Basel, Switzerland.

${ }^{7}$ Coulter Counter, Coulter Electronics, Hieleah, FL.

'Timbrell/Coulter Shearicon, Coulter Electronics, Hieleah, FL.
}

supplemented with soybean meal and minerals during the finishing phase of the trial. The cattle were slaughtered at approximately $433 \mathrm{~kg}$ live weight $(\mathrm{P}>.68$ for treatment differences; Crouse et al., 1987). The heifers were slaughtered in the U. S. Meat Animal Research Center abattoir; carcasses were graded (USDA, 1976) after chilling at $2 \mathrm{C}$ for $24 \mathrm{~h}$. Carcass data are reported by Crouse et al. (1987).

At slaughter, samples of subcutaneous adipose tissue were removed as quickly as possible after exsanguination and placed in a $.9 \% \mathrm{NaCl}$ solution at $37 \mathrm{C}$. Samples were obtained approximately $10 \mathrm{~cm}$ from the dorsal midline along the 12 th and 13 th thoracic vertebrae. Subsequently, $500 \mathrm{mg}$ of tissue were homogenized in $3 \mathrm{vol}(\mathrm{w} / \mathrm{v})$ of a buffer system containing .01M potassium phosphate and .154M KCl (pH 7.4). The homogenate was centrifuged at $27,000 \mathrm{~g}$ for $15 \mathrm{~min}$. The fat cake was discarded and the infranate was centrifuged again at $27,000 \mathrm{~g}$ for $30 \mathrm{~min}$. The supernatant fraction was assayed immediately for the activities of NADP-malate dehydrogenase (EC 1.1.1.40; Ochoa, 1955), fatty acid synthetase (Martin et al., 1961), glucose-6-phosphate dehydrogenase (EC 1.1.1.49) and 6-P-gluconate dehydrogenase (EC 1.1.1.44; Bernt and Bergemeyer, 1974).

Adipose tissue samples (100 to $150 \mathrm{mg}$ ) were stored at $-40 \mathrm{C}$ in screw-cap vials for cell size determinations. These samples were removed from the vials while still frozen and sliced to $1-\mathrm{mm}$ thickness, returned to the vials, and then fixed with osmium tetroxide by the method of Etherton et al. (1977). Particle number was determined ${ }^{7}$. Individual adipocytes were magnified microscopically, then manually measured $^{8}$ (100 to 200 cells per animal) and sorted into appropriate diameter channels for analysis. Diameters were reported as peak diameters, which is the diameter represented by the greatest number of cells. Using either peak diameter or mean diameter did not change the statistical evaluation of the cellularity data.

Adipose tissue lipogenesis in vitro was determined by incubating 100 to $150 \mathrm{mg}$ of fresh subcutaneous adipose tissue in flasks containing $5 \mathrm{mM}$ D-glucose, $5 \mathrm{mM}$ L-lactate, and $5 \mathrm{mM}$ acetate, in $3 \mathrm{ml}$ of Krebs-Henseleit $\mathrm{Ca}^{2+}$-free buffer. Flasks also contained $1 \mu \mathrm{Ci}$ of $\left[\mathrm{U} \cdot{ }^{14} \mathrm{C}\right]$ acetate. After incubating $2 \mathrm{~h}$, the reactions were terminated by the addition of $.5 \mathrm{ml} 2 \mathrm{~N} \mathrm{H}_{2} \mathrm{SO}_{4}$. Glyceride fatty acids were extracted by the method described by Smith and Prior (1982). 


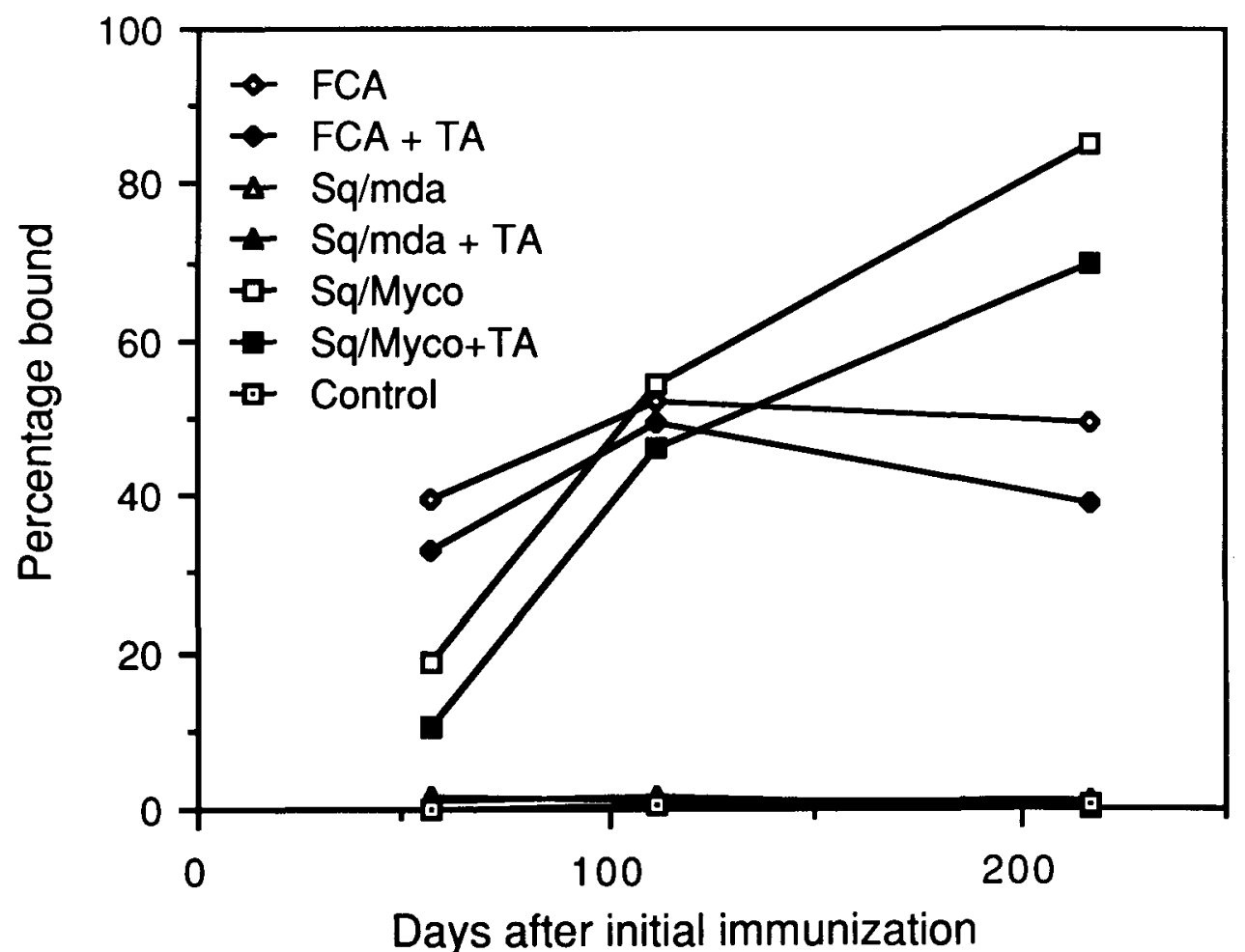

Figure 1. Percentage of ${ }^{3} \mathrm{H}$-labeled estradiol (approximately $28 \mathrm{pg}$ ) bound to 100 -fold diluted sera from control (saline-injected) heifers or in heifers actively immunized with $(1,3,5,10)$-estratrien-3,1 7 $\beta$-diol-6-one carboxymethoxime in Freund's complete adjuvant (FCA) or in saline: squalene/arlacel containing either Mycobacterium tuberculosis (Sq/Myco) or muramyl dipeptide adjuvant $(\mathrm{Sq} / \mathrm{mda})$.

All radioactivity was measured in a liquid scintillation counter ${ }^{9}$. Chemicals and radioisotopes were purchased from commercial suppliers $^{10}$.

Data were analyzed with the General Linear Model program (SAS, 1982); mean separation was achieved by Duncan's multiple range test (Ott, 1984). The model included the mean, replication and treatment. Residual variation was used as the error term.

\section{Results}

The squalene:arlacel:muramyl dipeptide adjuvant was ineffective in generating antibodies (figure 1). Consequently, animals receiving this adjuvant $(\mathrm{N}=2)$ were deleted from the statistical

\footnotetext{
${ }^{9}$ Beckman model LS 3800, Beckman Instruments, Palo Alto, CA.

${ }^{10}$ Fisher Scientific, Fairlawn NJ; Sigma Chemical Co., St. Louis, MO; J. T. Baker Chemical Co., Phillipsburg, NJ; New England Nuclear, Boston, MA.
}

analyses. Immunization with Freund's complete adjuvant or the Mycobacterium tuberculosis adjuvant elicited antibody production comparable to that reported by others (Wise and Ferrell, 1984; figure 1).

In the subsampling of this experiment, marbling scores did not change significantly among treatments. The adjusted fat thickness of the immunized group of our subsample was significantly greater than that of the control group, while the addition of trenbolone acetate implants in the immunized group reduced fat thickness to control levels (table 1). Ovariectomy in conjunction with trenbolone acetate elicited the least adjusted fat thickness in the subsample, which was substantiated by a significant decrease when the data were analyzed using all animals.

Ovariectomy in conjunction with trenbolone acetate caused the smallest cell diameter (table 1 ), indicating an atrophic effect. This diameter was significantly smaller than the diameters of adipose cells from the control, trenbolone 
TABLE 1. TREATMENT EFFECT ON ADIPOSE TISSUE CELL SIZE AND QUANTITY PER GRAM TISSUE AND ADJUSTED FAT THICKNESS

\begin{tabular}{|c|c|c|c|c|c|c|c|}
\hline Characteristics & CTLe & TA & ovX & OVX/TA & IMM & IMM/TA & C.V. \\
\hline Peak cell diameter ${ }^{\mathbf{a}} \mu \mathrm{m}$ & $176^{\mathrm{b}}$ & $166^{\mathrm{bc}}$ & $175^{b}$ & $145^{d}$ & $154^{\mathrm{cd}}$ & $159 \mathrm{bcd}$ & 9.8 \\
\hline Cells/gram, $\times 10^{-6}$ & $.36^{\mathrm{bc}}$ & $.37 \mathrm{bc}$ & $.29 \mathrm{c}$ & $.47 b$ & $.27^{c}$ & $.31 \mathrm{c}$ & 31.9 \\
\hline Adjusted fat thickness, $\mathrm{cm}$ & $.96^{\mathrm{c}}$ & $1.07 \mathrm{bc}$ & $1.12^{\mathrm{bc}}$ & $.76^{\mathrm{c}}$ & $1.42^{b}$ & $1.07^{\mathrm{bc}}$ & 33.9 \\
\hline
\end{tabular}

${ }^{a}$ Diameter represented by the greatest number of cells.

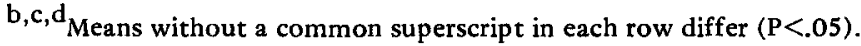

eAbbreviations: CTL, control; TA, trenbolone acetate; OVX, ovariectomy; OVX/TA, ovariectomy/trenbolone acetate; IMM, immunization; IMM/TA, immunization/trenbolone acetate; C. V., coefficient of variation.

acetate implanted or ovariectomized heifers. As expected, cells per gram tissue were increased by the ovariectomized/trenbolone acetate treatment and were significantly different from the ovariectomized treatment. The immunization treatment exhibited unusual results by causing a significant decrease in peak cell diameter compared with the control, but not resulting in an increased number of cells per gram tissue in comparison to the intact heifer. There was neither evidence of a bimodal distribution nor any other unusual characteristic of the cell size distribution (not shown) for any treatment group.

As observed for adjusted fat thickness, ovariectomy tended $(\mathrm{P}<.10)$ to increase acetate incorporation into fatty acids (figure 2 ) relative to intact heifers. Trenbolone acetate reduced acetate incorporation into fatty acids in adipose tissue from ovariectomized heifers to rates similar to control rates. However, trenbolone acetate had no observable effect on lipogenesis in the intact heifer. Immunization against estradiol, either alone or with the exogenous steroid, significantly increased the incorporation of acetate into fatty acids relative to the control, trenbolone acetate and ovariectomy/ trenbolone acetate groups (figure 2).

Fatty acid synthetase activity in adipose tissue from most treatment groups was similar to the control rate (table 2 ). The exception to this was the combined effect of estradiol-immunization and trenbolone acetate. This combination caused elevated fatty acid synthetase activity $(\mathrm{P}<.05)$. The activity of NADPmalate dehydrogenase was reduced significantly by trenbolone acetate treatment of ovariectomized heifers when compared with heifers ovariectomized alone, but not when compared with control animals.
Immunization against estradiol, in the absence or presence of trenbolone acetate, significantly increased the activity of glucose-6phosphate dehydrogenase when compared with either the control or the ovariectomy/trenbolone acetate group (table 2). A similar trend was observed for 6-phosphogluconate dehydrogenase activity.

\section{Discussion}

It is unknown whether immunoneutralization of estradiol potentiates the effects of estradiol or makes less of the hormone available to the receptors within the tissues. Although relatively few statistically significant effects were observed in this investigation, ovariectomy and

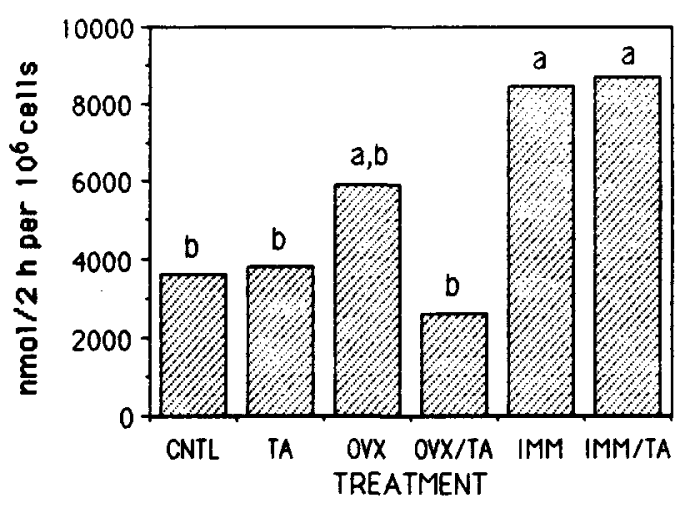

Figure 2. The incorporation of acetate into fatty acids in vitro in bovine subcutaneous adipose tissue. Incubation conditions as described in the text. Abbreviations as in table 1 . Means without a common letter differ $(\mathrm{P}<.05)$. 
TABLE 2. TREATMENT EFFECTS ON SPECIFIC LIPOGENIC ENZYME ACTIVITIESa

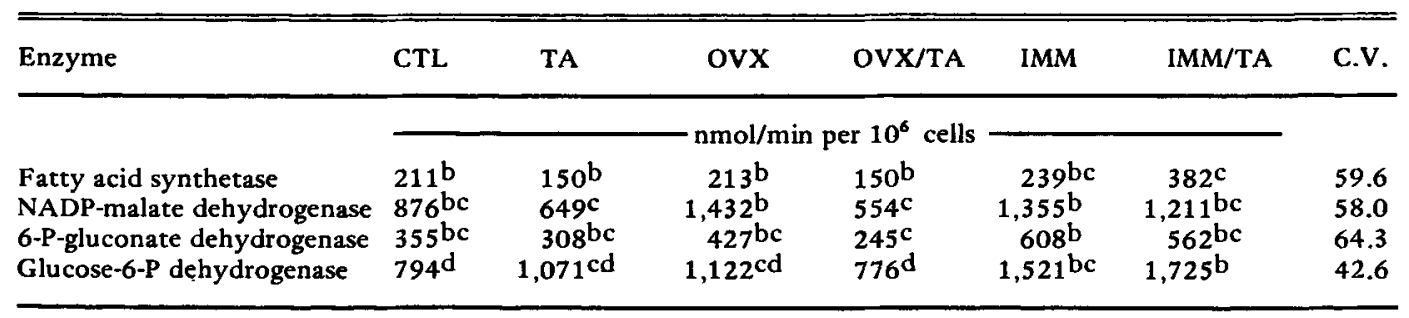

${ }^{\text {a Abbreviations as in table } 1 .}$.

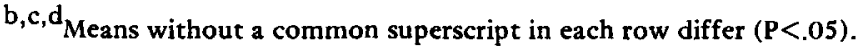

immunization consistently changed lipogenesis and fat thickness in the same direction relative to control animals. Thus, the data presented here suggest that the elevated lipogenic rates in both immunized groups, as in the ovariectomized group, were due to decreased availability of estradiol to the tissues.

In most situations, trenbolone acetate was able to reverse the effects of ovariectomy. However, trenbolone acetate did not reverse the effects of immunization on enzyme activities and lipogenesis from acetate even though fat thickness was reduced by trenbolone acetate to control levels. Because trenbolone acetate also had no effect in intact heifers, these results suggest that the actions of trenbolone acetate are blocked or masked by the presence of circulating estradiol.

It is unlikely that the elevated lipogenic capacity observed in the immunized/trenbolone acetate group was caused by compensatory hypertrophy of fat cells resulting from withdrawal of the trenbolone acetate $60 \mathrm{~d}$ prior to slaughter. As stated previously, adjusted fat thickness was less in this treatment group than in the immunized group. Furthermore, no compensatory gain response was observed in the ovariectomized/trenbolone acetate group.

Prior et al. (1983) demonstrated that implanting estradiol-17 $\beta$-dipropionate in steers had no effect on lipogenic enzyme activities, lipogenesis or fat cell size. In bulls, estradiol-17 $\beta$ dipropionate implants elicited elevated lipogenic enzyme activities (Prior et al., 1983). The stimulation of lipogenesis in adipose tissue from bulls was likely the result of the depressed plasma testosterone levels caused by the implants (Schanbacher et al., 1983). It is not clear why estradiol implants in steers had no effect on lipogenesis (Prior et al., 1983), while in heifers in the present study, the surgical or immuno- logical removal of estradiol resulted in elevated lipogenesis. Either inherent sex differences in estradiol receptors or the use of estradiol-17 $\beta$ dipropionate by Prior et al. (1983) may have been the basis for this apparent paradox.

While the present study indicates that trenbolone acetate decreased fat thickness in ovariectomized heifers by depressing lipogenesis, our investigation does not rule out the possibility of stimulated lipolysis in immunized heifers implanted with trenbolone acetate. It is possible that immunization and (or) ovariectomy affected carcass traits and lipogenesis through differential modifications in the synthesis or secretion of hormones other than estradiol. Heitzman and Chan (1974) documented no differences in plasma insulin, glucose, or nonesterified fatty acids in trenbolone acetate-implanted heifers as compared to non-treated heifers. However, trenbolone acetate also had no effect on fat thickness or lipogenesis in intact heifers (present study). Thus, the similarities in the effects of ovariectomy and immunization may have been coincidental, and this would help explain those situations where trenbolone acetate produced very different results in ovariectomized and immunized heifers.

Unusual results were observed for cell size determinations in the immunized heifers. In this particular group, peak cell diameter was decreased significantly compared with fat cells from the control heifers, in spite of the greater adjusted fat thickness and lipogenic capacity in adipose tissue from the immunized group. The smaller cell diameters should have resulted in greater numbers of cells per gram tissue, yet this was not the case. The biological bases for the anomalous results observed in the immunized heifers are unknown.

In summary, ovariectomy in conjunction with trenbolone acetate elicited the least acetate in- 
corporation into fatty acids, and the lowest NADP-malate dehydrogenase, 6-phosphogluconate dehydrogenase, glucose-6-phosphate dehydrogenase and fatty acid synthetase activities. Cell size for this treatment was significantly smaller than control. Trenbolone acetate elicited a decrease in subcutaneous adipose tissue thickness without any significant change in marbling scores, indicating that lipogenesis may be regulated differently in subcutaneous fat and intramuscular adipose tissue.

\section{Literature Cited}

Bernt, E. and H. U. Bergmeyer. 1974. 1974. Hexokinase. In: H. U. Bergmeyer (Ed.). Methods of Enzymatic Analysis. pp 624-631. Academic Press, New York.

Crouse, J. D., B. D. Schanbacher, H. R. Cross, S. C. Seideman and S. B. Smith. 1987. Growth and carcass traits of heifers as affected by hormonal treatment. J. Anim. Sci. 64:1434.

Etherton, T. D., E. H. Thompson and C. E. Allen. 1977. Improved techniques for studies of adipocyte cellularity and metabolism. J. Lipid Res. 18:552.

Heitzman, R. J. 1978. Anabolic agents in beef production: Their action as growth promoters. In: J. Martin de Boer (Ed.). Patterns of Growth and Development in Cattle. pp 353-359. Martinas Nijhoff, Boston.

Heitzman, R. J. 1979. The efficacy and mechanism of action of anabolic agents as growth promoters in farm animals. J. Steroid Biochem. 11:927.

Heitzman, R. J. and K. H. Chan. 1974. Alterations in weight gain and levels of plasma metabolites, proteins, insulin and free fatty acids following implantation of an anabolic steroid in heifers. Brit. Vet. J. 130:532.

Martin, D. B., M. G. Horning and P. R. Vagelos. 1961.
Fatty acid synthesis in adipose tissue. J. Biol. Chem. 236:663.

Ochoa, S. 1955. Malic enzyme. Methods Enzymol. 1:735.

Ott, L. 1984. An Introduction to Statistical Methods and Data Analysis (2nd Ed.). PWS Publishers, Boston.

Prior, R. L., S. B. Smith, B. D. Schanbacher and H. J. Mersmann. 1983. Lipid metabolism in finishing bulls and steers implanted with oestradiol-17 $\beta$ dipropionate. Anim. Prod. 37:81.

SAS. 1982. SAS User's Guide. SAS Institute, Inc. Cary, NC.

Schanbacher, B. D. and J. J. Ford. 1976. Seasonal profiles of plasma luteinizing hormone, testosterone and estradiol in the ram. Endocrinology 99:752.

Schanbacher, B. D., R. L. Prior and S. B. Smith. 1983. Effects of castration and subdermal silastic implants containing oestradiol-17 $\beta$-dipropionate on feedlot performance and carcass character istics of male cattle. Anim. Prod. 37:73.

Smith, S. B. and R. L. Prior. 1982. The effect of 3-mercaptopicolinic acid and substrate interactions on the incorporation of lipogenic precursors into glyceride-glycerol, glyceride-fatty acids and nonesterified fatty acids in bovine adipose tissue. Biochim. Biophys. Acta 712:365.

USDA. 1976. Official United States standards for grades of carcass beef. Title 7, Ch. 8, Pt. 2853, Sections 102-107. Code of Federal Regulations, USDA, Washington, DC

Wise, T. and C. Ferrell. 1984. Effects of immunization of heifers against estradiol on growth, reproductive traits, and carcass characteristics. Proc. Soc. Exp. Biol. Med. 176:243.

Young, V. R. and M. G. Pluskal. 1977. Mode of action of anabolic agents, with special reference to steroids and skeletal muscle. A summary review. Proc. 2nd Int. Symp. on Protein Metabolism and Nutrition, Eur. Assoc. Anim. Prod. Biddinghuizen. pp 13-26. 